\title{
FGFR3 Gene Amplification
}

National Cancer Institute

\section{Source}

National Cancer Institute. FGFR3 Gene Amplification. NCI Thesaurus. Code C129621.

A molecular genetic abnormality indicating the presence of multiple copies of the FGFR3 gene. 